\title{
Turkey's EU Candidacy and Civil-Military Relations: Challenges and Prospects
}

\author{
AYLIN GÜNEY AND PETEK KARATEKELIOĞLU
}

$\mathrm{T}$ he end of the Cold War has had important repercussions upon the traditional roles of the militaries in many Western and non-Western countries. This changing international environment with the start of new times, where postmodern militaries have emerged, has also led to a major revision of civil-military relations (CMR) theories. The collapse of communism and the bipolar world have paved the way for new times in which the armed forces face serious challenges amid the fundamental changes in the international context in which they operate and in the social structure of the societies in which they are embedded. ${ }^{1}$ Some theorists, such as Moskos, Williams, and Segal, argue that the militaries of these new times-which are prevalent mostly in the Western countries - can be labeled "postmodern militaries" since their threat perceptions and missions have changed to a great extent. ${ }^{2}$

Post-Cold War CMR theories not only aim to explain the impact of the international context upon the militaries of the West, but they also deal with the new context in which many non-Western countries are embedded. Unlike the previous emphasis on military coup d'états or praetorianism, these theories mostly point to the need for more democratic control of armed forces within

Aylin Güney is an assistant professor in the Department of Political Science, Bilkent University, Ankara, Turkey. Her academic interests include comparative politics (politics of the European Union and Mediterranean) and Turkish politics (civil-military relations). She has published articles in journals such as Armed Forces \& Society (co-authored with Metin Heper), Le Trimestre du Monde, Security Dialogue, and Futures, and has contributed several chapters to edited books (The Barcelona Process and Euro-Mediterranean, Political Armies). She currently teaches undergraduate courses on comparative politics, European integration, and World Politics. Address for correspondence: Asst. Prof. Aylin Güney, Bilkent University, Department of Political Science and Public Administration, Ankara, Turkey. E-mail: gaylin@bilkent.edu.tr

Petek Karatekelioğlu, PhD, is a graduate assistant in the Department of Political Science, Bilkent University. Her interest areas are European Union politics and comparative politics.

Armed Forces \& Society, Vol. 31, No. 3, Spring 2005, pp. 439-462. 
the larger framework of democratization. Most of the countries that are the subjects of these theories are the new democracies of the former communist Central and Eastern European (CEE) countries, who face a serious challenge regarding their roles in the new domestic and international political and strategic environment. ${ }^{3}$ More specifically, the military profession in these countries is faced with the problem of maintaining military effectiveness while responding to

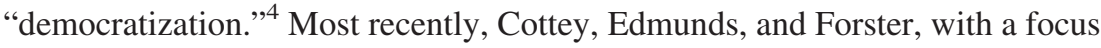
on the CEE postcommunist regimes, have pointed out "the necessity of reconceptualizing civil-military relations in terms of democratic governance of the defense and security sector and the democratic legitimacy, governance and accountability of a state's civil-military relationship." They refer to this as the second-generation problematic.

Some recent CMR theories deal with outside triggers that play an important role in democratizing civil-military relations in these countries. These theories point to the importance of a number of transnational institutional structures that have been established with the specific aim (among others) of encouraging the democratization of civil-military relations. ${ }^{6}$ They further argue that the combination of transnational norms and institutions, backed up by political conditionality, create strong pressures for the CEE countries to democratize their civil-military relations. The applications of the CEE countries in the 1990s for membership in the European Union (EU), their accession in May 2004, and their inclusion within the enlarged North Atlantic Treaty Organisation (NATO), reinforced the importance of the consolidation of democracy and encouraged the political and military leaders in these countries to adapt to the standards of the Western democracies, since the existence of a smoothly functioning democracy is a sine qua non for membership as set forth at the Copenhagen European Council in 1993. NATO and the EU are institutions through which the West has been using conditionality to encourage the democratization of CMR in central and eastern Europe, and more specifically the "democratic control of the armed forces." 7

Although the CEE countries are examined in depth by CMR theories, there is neglect in the case of Turkey, which has a rather controversial position regarding this matter. Turkey has been a member of NATO since 1952, and therefore NATO membership has not been a precondition for democratic control of its armed forces. Instead, Turkey's long struggle to become a member of the EU in accordance with its modernization and westernization program has acted as an important outside trigger for democratization. Turkey had signed an Association Agreement with the European Economic Community (EEC) in 1963, much earlier than the CEE countries. However, as of yet, it has not been given a date for the start of negotiations for EU membership due to the non-fulfilment of the "political chapter" of Copenhagen criteria. One of the most impor- 
tant conditions among the political criteria has been the democratic control of the military in Turkey.

This study is a single-case design that aims to test the CMR theories regarding the impact of transnational factors upon democratic control of the military by examining the Turkish case. The authors will test this theory by looking at the evolution of the traditional guardianship role of the Turkish military and its institutional reflections in the light of the conditions put forward by its EU candidacy.

\section{Armed Guardians of Turkish Democracy}

As one of the key countries that had felt the impact of the Cold War due to its geographic and geostrategic location, Turkey was an extremely important component of Western strategy toward the Soviet Union. As the only secular and democratic country having a 99 percent Muslim population, the Western world viewed Turkey as a bulwark against the communist threat and as an important asset against Islamic fundamentalism that could emanate from the Middle East and Asia. Therefore, Cold War developments between the communist and capitalist blocs had important implications for domestic politics in Turkey, with the Turkish military playing an important role in this context. Likewise, the end of the Cold War and the disappearance of the bipolar character of world politics forced the Turkish military to redefine its relations with the civilian elite and also to deal with the challenges to its traditional guardianship role that emanated from Turkey's increasing interest and strong determination to become a member of the EU.

The Turkish military, composed of approximately $800,000^{8}$ personnel, is the most prominent security structure in Turkey. It has frequently been the object of major criticisms from the EU regarding the lack of democratic control over the institution. Due to its recent direct interventions in politics (1960, 1971, 1980) and its indirect intervention in 1997, the Turkish military has been classified among the "political armies" of the world. ${ }^{9}$ In addition, the "autonomous" $" 10$ role played by the military in Turkish political life is regarded as a major impediment to democratic consolidation; Turkish officers' attempts to bolster their autonomy from civilian governments with the argument that they have always had a special relationship with the people - and thus a power base of their own-do not exactly conform to the model of civil-military relations in a liberal democracy. ${ }^{11}$

The autonomous role of the Turkish military in the politics of the country can best be understood by inspecting its past and the historical heritage that forms the backbone of its ideology. As described below, three important historical legacies have had an impact upon the construction of a guardianship 
role $^{12}$ (i.e., the protection of the Turkish Republic from any Islamist or separatist threats).

1. The Ottoman legacy, against which the military developed a mentality of modernization and Westernization, and a Young Turk tradition from which military activism in politics is inherited. ${ }^{13}$

2. The legacy of the Turkish War of Independence, which legitimized the Turkish military in the eyes of the Turkish people. ${ }^{14}$

3. The legacy of Mustafa Kemal Atatürk and the Kemalist ideology that furnished the military with principles of secularism, democratic order, and integrity of the republic. ${ }^{15}$

These three factors are not sufficient by themselves to explain the present role of the military in Turkish politics. Equally important is the existence of "triggering" factors, ${ }^{16}$ those changing strategic, political, social, and economic dynamics within the domestic and external context. It is important to note that changes in threat perceptions are extremely important in determining the context of civil-military relations and the degree to which democratic control can be exerted over the military. However, political leaders have failed to coordinate their activites and impose civilian supremacy over the military institution. ${ }^{17}$

According to one scholar,

[C]ultural and institutional factors offer a clear explanation of civilmilitary relations in Turkey. Despite their formal separation, military and civilian authorities have forged a partnership based on an imperfect concordance among the military, political elites and the citizenry. This ruling style is the product of Turkey's specific cultural, social and institutional context, featuring a stratified society and political culture as well as historic conflicts with neighbouring states. Such conditions significantly influence the military's role in the nation. ${ }^{18}$

It is also important to consider the importance of the Kemalist heritage which forms the foundation of the mentality of the Turkish armed forces. A definition of Kemalism is as follows:

Kemalism is the set of realistic ideas and principles concerning the state, the economy, intellectual life, and the fundamental social institutions. The basic principles were also laid down by Ataturk to ensure the full independence, peace and welfare of the Turkish nation in the present and the future, to ensure the sovereignty of the nation as the 
basis of the state, and to raise Turkish culture to the level of modern civilization under the guidance of rational and scientific principles... The adoption of Atatürkism on an individual and nation-wide basis and its protection against current and prospective movements of a deviant and conservative nature serve as the guarantee for the development, strength and enlightened future of the Turkish state. ${ }^{19}$

For the officers, modernization meant Westernization and an important component of Westernization was democracy. Their definition of democracy can be likened to Giovanni Sartori's "rational democracy"; that is, understanding democracy as an intelligent debate among the educated for the purpose of deciding upon the best policy option. ${ }^{20}$ In this respect, the military's definition is much closer to the maintenance of order than democracy per se. The Turkish military argues that it accepts the legitimacy and supremacy of democratic ideals and civilian rule, and defends the ideals of the democratic and secular character and integrity of the Turkish Republic, due to the strong Kemalist legacy that it inherited. The military upholds Kemalist values; when civilian regimes are perceived as deviating from these values, the military has intervened to "put things in order."

The recent role of the military in Turkish politics is also due to the lack of a strong democratic tradition, which reveals itself in the functioning of various agents in Turkish democratic and political life. Petty party politics, the high level of corruption among the civilians, and their inability to solve political and economic crises have left room for the military to enter politics, fill the "vacuum," 21 and act as the guardians of the Republic. Thus, the negative image of politicians is a source of differences between the military and the civilian worlds. The majority of the cadets interviewed at the military schools and academies view a politician as someone who puts his personal interests or his party's interests before those of the nation. ${ }^{22}$

Finally, the role played by the military in Turkish political life is closely related to the internal threats that are perceived as endangering the democratic and secular character of the Republic as well as its integrity and its unitary structure. In this respect, the reemergence of the Kurdish problem in the 1980s, and the rise of political Islam in Turkey in the 1990s, were important factors that indirectly pushed the military to enter Turkish politics once again—although the modes of intervention have changed over time.

\section{The Problem of Democratic Control over the Turkish Military}

The major criticisms directed by the EU at the Turkish military concern mostly the institutional aspects of democratic control. In this respect, the status 
of the chief of the general staff under the prime minister (instead of the Ministry of National Defense), the role of the National Security Council (NSC) in Turkish political life, and the lack of an effective civilian or parliamentary control over the military budget are the issues related to civilian oversight. ${ }^{23}$

\section{Problem of Accountability}

A serious criticism directed at the Turkish military concerns the status of the chief of the general staff under the prime minister. This special status has its roots in the establishment of the Turkish Republic in 1923 and the years that followed under single-party rule (1923-1946). The first step in establishing civilian control over the military was realized on May 30, 1949, with a law which subordinated the chief of general staff to the Ministry of Defense. This step was part of the process of transition to multiparty democracy started in 1946, and it aimed to regulate civil-military relations as in Western democracies. The military cadres were by no means opposed to this move, since the project was begun by the "Second Man" of the Kemalist Republic, İsmet İnönü. ${ }^{24}$

According to the 1961 Constitution, which was enacted after the coup d'état on May 27, 1960, the chief of the general staff was defined as the commander of the armed forces and therefore was made responsible to the prime minister. As a consequence of this duality, the Constitutional Court found the law determining the status of the chief of the general staff incompatible with the 1961 Constitution. Following amendments in 1970, two laws were passed; according to these laws, "the Chief of the General Staff would determine the priorities and principles and main programs concerning personnel, intelligence, mobilization, education, and logistics." It was also stated that, "in determination of the military aspects and implementation of international agreements, the Chief of the General Staff would be consulted. It may participate in those meetings if it is deemed necessary. ${ }^{, 25}$ For this reason, Turkey is still represented in organizations such as NATO by personnel at the level of the chief of the general staff. The Ministry of National Defense, on the other hand, is responsible for the political, legal, social, financial, and budgetary services for national defense in the framework of the defense policy of the armed forces. The defense policy, in turn, is agreed upon by the Council of Ministers according to the principles, priorities, and major programs as determined by the chief of the general staff.

It was only during the government of Turgut Özal in the late 1980s that the government made a show of strength in establishing political authority over the military. The role of the armed forces in Turkish society, and within the governmental structure of the Republic, was debated openly. This debate revolved around the notion that the armed forces were protectors of democracy on the one hand, and on the other hand that "praetorian guardianship could only impede the 
development of civil-societal institutions essential for obtaining a functioning democratic system. Consequently, this would leave the military outside of any supervision, which might lead democracy to experience serious bottlenecks in the future." ${ }^{26}$ The taboos regarding civilian involvement in matters related to the internal organization and funding requirements of the military, including the defense budget, were also broken by the Özal administration. In 1987, Özal started to review the defense budget and initiated public discussion of the resource requirements for the professionalization of the military as a whole. A few months later, Özal declared his intention to make the chief of the general staff report to the defense minister if his government obtained a sufficient majority of the seats in parliament after the elections. His plan was not implemented because his party gained less than a two-thirds majority of votes in the parliamentary elections - the minimum number of votes required to make constitutional amendments. Moreover, these attempts by Özal had not found any relevant support from fellow party leaders and the people. ${ }^{27}$

Nevertheless, the Ministry of Defense assumed greater authority over defense requirements during Özal's regime, and the military budget was openly discussed. According to one scholar, it was probably no coincidence that a public relations department was formed in the Office of the General Staff soon after these issues came under public scrutiny. ${ }^{28}$ At present, the military still insists on the necessity of the chief of the general staff reporting directly to the prime minister instead of the minister of national defense. The main reason behind this insistence is the desire to prevent the politicization of the military (as had occurred in the 1950s). The military contends that if it were subordinate to the minister of defense, a chief of general staff might easily be replaced depending on political preferences. Moreover, it is also possible that some regime opponents may come to power through democratic process. In that case, an opponent cannot be allowed to shape the Turkish armed forces according to their own understanding. ${ }^{29}$

\section{The National Security Council}

The NSC is another "undemocratic" mechanism that has been criticized in the yearly regular reports of the European Commission because of a lack of effective democratic control over it. The NSC is defined in the Constitution as a constitutional consultative organ chaired by the president, and includes the following members: the prime minister, chief of the general staff, minister of national defense, minister of interior affairs, minister of foreign affairs, commander of land forces, commander of naval forces, commander of air forces, and general commander of gendarmerie. Other ministers and officials may be invited to the meetings to share their opinions depending on the nature of the 
agenda. The decisions of the NSC are formulated in line with the definition of the concept of national security. Therefore, this concept of national security is crucial to assess the role played by the NSC in Turkish political life. The Act of the National Security Council and National Security Council General Secretariat dated December 9, 1983 (No. 2945) defines national security as the "protection and maintenance of the state's constitutional order, national presence, integrity, its political, social, cultural and economic interests on an international level and contractual law against any kind of internal and foreign threat." ${ }^{30} \mathrm{In}$ this context, the NSC's agenda includes any matter that is perceived as relevant to national security. The NSC advises the Council of Ministers of its views on the determination and implementation of national security policy as well as required coordination. The decisions made by the NSC have to be given priority for evaluation by the cabinet.

During the 1990s, Turkey's determination to become a member of the EU reached its height. The Turkish military supported this move since it was perceived to be in line with the Kemalist ideology that praised Westernization and modernization. However, the 1990s were also the years in which the military had to work through the NSC to fufill its traditional role of guardian of the Turkish Republic against two major axes of conflict: the rise of political Islam accompanied by an increasing number of reactionary Islamic activities, and the prolonged conflict in southeastern Anatolia between the Partita Karkaren Kurdistan (PKK, the Kurdish Workers' Party) and the Turkish military. On April 29, 1997, the military's "new wars" were defined by the Turkish chief of the general staff, who announced a radical change in the national military defense concept embodied in the National Security Policy Document (NSPD): priority would be given to combating internal threats from Islamic activism and Kurdish separatism, rather than safeguarding the state against interstate wars and external threats.

On October 31, 1997, the NSC accepted the NSPD, which included a list of measures that had been prepared by the NSC and submitted to the Council of Ministers, and which laid down the principles that the NSC considered vital. In summary, the redefined principles stated in part that separatist and reactionary activities were equally important threats to the Republic which should be given priority, and that political Islam continued to be a threat. These changes in focus were signals that the NSC would play a larger role in the near future.

\section{The Military, Political Islam, and the "Postmodern Coup"}

The political role played by the NSC first attracted attention following decisions made on February 28, 1997 to counter the increasing reactionary activities of political Islam which were believed to threaten the secular and democratic pillars of the established order. ${ }^{31}$ The military wing of the NSC voiced its dis- 
content with this situation. The main target of their harsh complaints was the coalition government, led by the religiously oriented Refah Partisi (RP, Welfare Party). The party was known for its religious rhetoric; when this rhetoric was put into practice, the military was alarmed. Some of the RPs practices included the adoption of Ramadan (the holy month of fasting in Islam) hours in governmental organizations, increasing the financial strength of religious entities, and increasing the number and activities of religious orders as well as prayer leader and preacher schools. The military's unease was exacerbated by additional factors such as the foreign policy of the coalition government and the public remarks of some Welfare Party deputies attacking Kemalist secular and democratic principles. For instance, on April 13, 1994, Prime Minister Erbakan asked Refah's representatives in the parliament to consider whether the change in the social order that the party sought would be "peaceful or violent," and would be achieved "harmoniously or by bloodshed." 32 On March 23, 1993, in a speech to the National Assembly, Erbakan advocated the "plurality of legal systems" and stated: "We want despotism to be abolished. There must be several legal systems. The citizens must be able to choose for himself which legal system is the most

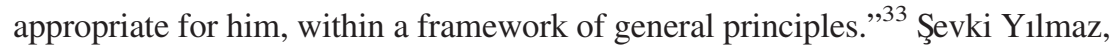
a Refah deputy, said in public speeches in 1994: "Our mission is not to talk but to implement the war plan as a soldier in the army ${ }^{34}$... The question Allah will ask you is this: 'Why, in the time of the blasphemous regime, did you not work for the construction of an Islamic State?' Erbakan and his friends want to bring Islam to this country in the form of a political party." ${ }^{35}$ Hasan Hüseyin Ceylan, another Refah member of parliament, stated publicly on March 14, 1993, "Our homeland belongs to us, but not the regime, dear brothers... The regime and Kemalism

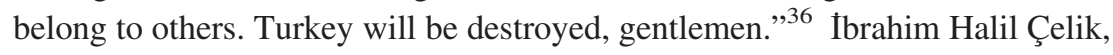
a Refah leader, exclaimed in Parliament:

If you try to close the Prayer Leader and Preacher Schools while Refah is in government, blood will flow. It will be worse than in Algeria. I too would like blood to flow. That's how democracy will be installed in this country... The army has not been able to deal with the 3,500 members of the PKK. How will it deal with six million Islamists? If they [the army] piss into the wind they'll get their faces wet ... I will fight to the end to introduce the Sharia. ${ }^{37}$

The mayor of the city of Kayseri, Şükrü Karatepe, stated in the party meeting after the Memorial Day of Atatürk ceremony on November 10, 1996:

Don't think I am a supporter of secularism. I have to attend these ceremonies in spite of myself... This system must change. We have 
waited, we will wait a little longer. Let us see what the future has in store for us. And let Muslims keep alive their resentment, rancour, and hatred that they feel in their hearts. ${ }^{38}$

Last but not least, Prime Minister Erbakan received religious leaders at his official residence, an act that was perceived by the military as an assurance of his support for them. ${ }^{39}$ The meeting with these leaders (who were wearing religious attire forbidden by the Dress Code), together with the above-mentioned public statements, were perceived as official recognition of these religious orders by the state. For the military, such actions were seen as undermining the secularist pillar of the Turkish Republic.

Despite these alarming developments, the military did not opt for direct intervention as in the past. Instead of assuming power, it chose to voice its discontent at the NSC. The decisions of February 28, 1997, were perceived as an ultimatum by the civilian government, and this "indirect intervention" in Turkish politics was regarded as a "silent coup d'état" or a "post-modern coup.",40 The crisis was solved by the resignation of Prime Minister Erbakan.

The main reason why the military was perceived as intervening in politics was not simply the decisions of February 28, 1997, but also the insistence by the military NSC members on controlling whether these decisions were implemented. Other reasons included the briefings given to various civil society organizations by the chief of the general staff informing them about the nature of the Islamic threat, and also the declarations and statements of the military. In sum, the February 28 decisions resembled the "coup by communiqué" of 1971. Some commentators also argue that the Batı Çalışma Grubu (BÇG, Western Study Group) that was formed by commanders in the general staff headquarters was a sign that the military was acting on its own without consulting any civilian authority. ${ }^{41}$

The year-long (1996-1997) coalition government, which included representatives from Refah Partisi and Doğru Yol Partisi (DYP, the True Path Party), was quite significant in assessing the role of the military in the NSC. It is ironic to note that when the democratic regime faced the threat of political Islam, expressed in such a way as to infringe upon the untouchable principles of the Republic, democratic control of the military was not even questioned. On the contrary, the military had quite strong support from many segments of society (e.g., some media and civil society organizations that had been critical of the military's role in previous interventions). This time, the military's role was seen as legitimate by the populace. Ironically, the military was perceived as the only institution that could safeguard the democratic regime and the constitutional order without resorting to arms. The military regarded its new mission 
as twofold, as explained by Commander of the Navy Güven Erkaya, in a later interview:

First, to help the people realize this threat and second to mobilise the civilians against this threat. In other words, this "coup" should be made by the civilians ... the military never wanted to make a coup d'état. The Turkish Armed Forces evaluated the possibility of a reactionary threat sliding to the street, and thus took measures. That is all that has been done. We thought, if some people want to make Turkey an Iran and desire to bring a theocratic regime instead of democracy, we should first try to deter them by "rhetoric." This has been done. This has been told to them in legitimate platforms [as] in the NSC meeting face to face. This was a test, a democracy test. Turkey passed this test. Now, even if a similar thing happens in the future, Turkey has this experience. The experience of overcoming a reactionary threat in the Parliament is a great experience. It is an important experience. ${ }^{42}$

Indeed, according to the military, the intervention on February 28 was a "democratic reaction," and the armed forces acted like any other civil society organization against the perceived Islamic threat. ${ }^{43}$ The concept of democratic reaction denotes that the religiously led coalition government was pressured to resign for the sake of preserving the secular and democratic principles of the Republic, upon which the government's Islamist policies and activities were infringing.

\section{The Turkish Military, the Kurdish Problem, and the EU}

The Kurdish separatist movement was another important factor that led to a political role for the Turkish military in the 1980s and 1990s. The direct involvement of the armed forces in a sort of guerilla warfare with the PKK since 1984 was a matter of critical debate (especially in the European countries) regarding the Turkish army's role in national politics. The struggle was perceived by many Western democracies, as well as the EU, as a war against the Kurdish population in southeastern Anatolia, who wanted to establish their own state.

However, the military's internal security role in combating the PKK had a legal basis. The struggle was carried out entirely under the command and management of the legal civilian authority. A State of Emergency Regional Governorship and a Public Order Command of Gendarmerie were established by decree (under Act No. 285) to make the struggle against terrorism more effective, and those efforts took place under the responsibility of the Interior Ministry in line with the State of Emergency Act 2985. According to this latter Act, when 
a state of emergency is in effect, the regional governor may employ military forces to combat terrorism if necessary.

The physical defeat of PKK occured after the head of the terrorist organization, Abdullah Öcalan, was finally arrested. The move by the militarywhich threatened to declare war against Syria unless it stopped providing the terrorist chief with accommodation-was a decisive step. The result was the expulsion of Öcalan from Syria. Öcalan was finally arrested in Kenya in 1998 and returned to Turkey, along with the other heads of the terrorist organization. Since then the terrorist activities have been under control. However, the military was not outspoken regarding the death sentence later passed on Öcalan; they stated that "it is first the judiciary and then the Parliament who would decide the issue according to the Constitution." 44 The arrest of Öcalan increased the credibility of the army in the eyes of the Turkish public. An opinion poll revealed that the army was credited as having the primary role in the successful arrest of Öcalan. ${ }^{45}$

After the arrest of Öcalan in 1998, the decreasing intensity of the armed conflict in southeast Anatolia allowed the military to review its mission there and prompted discussion of the legal arrangements that would be needed to grant rights (such as education, broadcasting, etc.) to the Kurdish citizens of Turkey. Since these legal amendments constitute a part of the political criteria that Turkey has to fulfill in order to become a member of the EU, attention focused on the military's possible reaction to such amendments. While the military stated that it genuinely supported Turkey's EU membership, they remained sensitive about certain issues.

In the context of the National Security Document chapter on "Protecting Minority Rights," the NSC argued that recognition of Kurdish identity or permission to operate Kurdish-language television channels would fuel separatism and damage Turkish national unity. In addition, the NSC declared that the authority to restrict human rights should be given to the state in case of emergency, while at the same time allowing Turkey to harmonize with the Copenhagen criteria on other issues. ${ }^{46}$

\section{The EU and the Turkish Military}

The method used to accomplish the indirect coup of 1997 was chosen primarily to protect Turkey's prestige in the eyes of the EU, which Turkey was aspiring to join. The military expressed its view of the issue in the National Strategy Document, stating that "the objective of Turkey's full membership of the EU should be maintained, yet the negative attitudes of some member states should not be disregarded." ${ }^{\text {" }}$ This concern was also voiced by some senior generals, who openly criticized the preference of some European member states as 
a "visionless" strategy that tended to exclude Turkey from the new map of Europe. ${ }^{48}$ The generals also claimed that the new political and security architecture being forged would fail to secure a stable environment for Europe in the long term: it was creating artificial borders in Europe; seemed unable to contribute to European unity; and would not help in any way to transform the Balkans, the Mediterranean (particularly the eastern Mediterranean), the Black Sea, the Caucasus, Ukraine, Belarus, and the Russian Federation into safe and stable regions. ${ }^{49}$ Coming just before the Luxembourg European Council meeting in December 1997, such statements by high-ranking generals revealed that they very much "resented the attitude of Europe, and criticized the EU for keeping Turkey outside and adopting an attitude that almost ignored and even complicated Turkey's legitimate security requirements."50

The EU's criticisms of Turkey with respect to democratic control of the military and the political role of the NSC were mentioned in the 1998 Progress Report on Turkey prepared by the Commission of the European Union. In that report, the military's political role was regarded as a major obstacle to the consolidation of Turkish democracy. Although there was no direct reference to specific issues (e.g., political Islam or the Kurdish problem), EU criticism of the NSC's role was quite strong.

The Regular Report of the Commission on Turkey's Progress Towards Accession, dated October 13, 1999, stated that

[T]hrough the National Security Council, the military continues to have an important influence in many areas of political life... The National Security Council continues to play a major role in political life. While the emergency courts system remains in place, the replacement of the military judge by a civilian one in the State Security Courts, represents a clear improvement in terms of the independence of the judiciary. ${ }^{51}$

The problems of democratic control of the military also gained prominence after the Helsinki European Council held on December 10-11, 1999. That assembly produced a breakthrough in EU-Turkey relations with the announcement of Turkey's candidacy status. The Presidency Conclusions of the European Council stated that:

Turkey is a candidate state destined to join the Union on the basis of the same criteria as applied to the other candidate states. Building on the existing European Strategy, Turkey, like other candidate states, will benefit from a pre-accession strategy to stimulate and support its reforms. This would include enhanced political dialogue, with emphasis on 
progressing towards fulfilling the political criteria for accession with particular reference to the issue of human rights. ${ }^{52}$

The military reacted positively, and stated that they gave full support to the EU decision in this respect. However, as mentioned above, the developing relations between Turkey and the EU had some important repercussions upon the guardianship role of the military. At every opportunity, the EU voiced its uneasiness with the army's powerful role in Turkish politics and criticized the NSC for being an undemocratic institution. The autonomous role of the NSC constituted a problem for Turkey in meeting the political requisites of membership described in the Copenhagen criteria, and was even regarded as an "obstacle" to full membership of Turkey in the EU. ${ }^{53}$ The Progress Report on Turkey for 2001 restated the EU's worries about the NSC's role in Turkish politics. The report stated that there had been no change in the role of the NSC, and that it seemed that the NSC's presence put serious limitations upon the functioning of the government. In addition, the report reiterated that it seemed "there is a great lack of parliamentary control over the issues related to defense and security," and therefore proposed that Turkey increase the number of civilians on the NSC from five to eight. The military's response to this proposal was again quite positive; the chief of general staff stated that "the number of the civilians can even be increased to 100. It does not matter. The NSC takes decisions by consensus under the chairmanship of the President, not by lifting fingers." ${ }^{, 54}$ In response to this EU proposal, representatives of the Human Rights Coordinating High Council, the Ministry of Finance, and the Ministry of Justice, together with the vice prime ministers, are now present at NSC meetings.

Another EU criticism concerned the status of the Office of the Chief of the General Staff. The chief of the general staff is appointed by the president, and is responsible to the prime minister. The EU's argument is that in developed democratic regimes, the chief of the general staff should be responsible to the Ministry of Defense, and this should be the case in Turkey. However (as explained above), the Turkish military opposes this proposal, stating that the present arrangement is due to the sui generis status of the military in Turkey.

Despite its firm official commitment to maintain the integrity, secularity, and democratic character of the Turkish Republic, the Turkish military clearly seems aware of the need to modify its strategies and policies to interact more with civilians, to be as transparent as possible, and not to impede democratic consolidation in Turkey. One example of such initiative is the preparations for the "brainstorming" or "brown-bag" meetings of the chief of the general staff and the press. The aim of these meetings was "to avoid incomplete and misinformation for the people inside and outside Turkey on important issues concerning Turkey." 55 Moreover, in line with its strong determination and support 
for Turkey's EU orientation, the Office of the Chief of General Staff established an EU Working Group in early 2000 to plan the military's actions during the harmonization process with the EU. Similar working groups were also established within the headquaters of the Turkish Army, Navy and Air Force with the same objective. ${ }^{56}$

The Regular Report of the EU Commission on Turkey's Progress Towards Accession, dated November 8, 2000, stated that:

[T]here has been no change in the role played by the National Security Council in Turkish political life. Its conclusions, statements and recommendations continue to strongly influence the political process, as witnessed in the recent debate over the dismissing of civil servants suspected of links with radical Islamic and separatist movements. In addition, it appears that at present the views of the National Security Council in practice seriously limit the role played by the government. Moreover there seems to be too little accountability to the Parliament with regard to defence and security matters. It is noted that the possibility of increasing the number of civilian members of the National Security Council is currently under debate within political and military circles. ${ }^{57}$

It was only after the preparation and submission of the National Program that the Regular Report from the Commission on Turkey's Progress Towards Accession (dated November 13, 2001) stated that, "as part of the constitutional reform package, the provision of Article 118 concerning the role and composition of the National Security Council has been amended. The number of civilian members of the NSC has been increased from five to nine while the number of the military representatives remains at five." In addition, the new text put emphasis on the nature of this body, stressing that its role would be limited to recommendations. The government would now be required to simply evaluate the NSC's recommendations instead of giving them priority consideration. However, the report also stated that the extent to which the constitutional amendment would enhance de facto civilian control over the military would need to be monitored. Since the last Regular Report was prepared, the NSC has given its opinion on a number of governmental issues and policies, including the Cyprus issue, the European Security and Defence Policy (ESDP), measures to combat antisecular activism, extension of the compulsory age limit in primary education, the state of emergency in various provinces, the privatization of state companies (e.g., Telecom), recent socioeconomic developments, and the constitutional reform package. The NSC has also warned against the risk of social unrest. 
It is interesting to note that the reactions of the Turkish military toward EU policies have been affected to a great extent by critical statements made by EU leaders. One of the foremost topics that has shaped the military's attitude is the issue of ESDP. In December 2002, EU leaders at the Laeken Summit decided to announce that the Political and Security Committee as well as the Military Committee-both core institutions of the European Army-would become operational. This decision meant that the EU would have the authority and ability to launch humanitarian interventions in low-intensity crisis situations without seeking NATO's assets and capabilities.

In the London talks between the United States, Turkey, and Britain, Turkey raised several points that it deemed critical to its own interests. They included a request to participate in the ESDP military secretariat on a permanent basis with a military representative. This request was not accepted by EU officials. The Turkish authorities also pointed out that:

[I]n the case of autonomous EU operations that do not require NATO assets, once Turkey states that the operation lies within geographic proximity to its territory or affects its vital interests, the EU must assure Turkey of participation in the decision-making process and the operation. Turkey sought an automatic invitation to be made by the ESDP for the operations to be staged in Turkey's proximity such as the Balkans where Turkey does not have any bilateral dispute but has a close interest. ${ }^{58}$

The EU acted reluctantly in giving Turkey such assurances, and this caused resentment on the part of the Turkish military—who had assessed the issue on the basis of national security. Turkish War Academies Commander Nahit Şenoğul stated that:

[T]he fact that the EU has ignored the decisions taken at the Washington Summit in its Nice Summit and decided to exclude Turkey from the ESDP and to postpone its membership to post-2010 is seen as an unfair and disloyal EU attitude towards Turkey and causes the feeling of being deceived to arise on the part of Turkey."59

The future implications of being left out of the ESDP, according to the army, would be twofold: "the efficiency of NATO and transatlantic relations will erode and the EU will engage in security operations in a manner that might negatively affect Turkey's security interests."60

Another example of the Turkish military's recent reactions to the EU is revealed in the words of former Chief of the General Staff Hüseyin Kıvrıkoğlu, 
who stated that "despite the fact that Turkey has its face turned to the West, in Europe there is still a centuries-old feeling of 'exclusion' towards the Turks.",61 In another instance, he had stated that "according to new research published, the Europeans do not consider the Serbs, the Albanians and the Turks as Europeans. What we have to do is to change the perceptions of the Europeans towards Turkey. We definitely have to correct our image there." ${ }^{\text {, }}$

It has been clearly stated, at every opportunity, that the Turkish military respects and supports Turkey's European orientation. Yet the military have felt the urge to warn against infringing upon the two "untouchable republican principles" of secularism and unity. The following statement by Kıvrıkoğlu is worth noting in this respect:

The armed forces do not even discuss the issue of whether Turkey should enter the EU or not. The membership of the EU will assure so many benefits for Turkey. Turkey wants to increase its welfare, and this could be done much more easily in the EU. Turkish people and the bureaucracy will gain a discipline and dynamism and have to comply with some rules. However, what we say is that the critical position of Turkey, the geo-strategic position of Turkey that always creates problems, should be taken into consideration as the membership efforts are made. Do not ignore the secular character and unitary structure of Turkey. These are the main principles of the Republic of Turkey. Numerous freedoms will be available if Turkey becomes a member of the EU. However, these should not violate democracy and human rights. $^{63}$

In the same vein, the 2002 revision of the 1997 National Security Document culminated in a serious civil-military dispute. In a statement, Deputy Prime Minister Mesut Y1lmaz criticized Turkey's national security understanding and claimed that progress was being hampered by such a syndrome. ${ }^{64}$ The military reacted rather harshly, and stated that "it was not only unfortunate but also dangerous to blame the national security concept for negative developments in the country," and that "national security should not be an issue of political exploitation." 65

\section{The EU Candidacy and Democratic Control in Turkey}

A number of fundamental changes have been made to the legal framework of the NSC with a view to aligning relations between civil and military authorities with the practices of EU member states. For instance, as stated in the 2003 Regular Report of the European Commission, "the advisory nature of the NSC 
was confirmed in a law implementing the amendment of October 2001 relating to Article 118 of the Constitution, which also increased the number of civilians in the NSC." In addition, an amendment to the Law on the National Security Council abrogated the provision that "the NSC will report to the Council of Ministers the views it has reached and its suggestions."

The NSC representative to the Supervision Board of Cinema, Video and Music was removed by an amendment to the relevant law. However, an NSC representative remains on other civilian boards, such as the Radyo Televizyon Üst Kurulu (RTÜK, High Audio-Visual Board) and the Yüksek Öğrenim Kurulu (YÖK, Higher Education Board).

The seventh reform package adopted in July 2003 introduced some fundamental changes to the duties, functioning, and composition of the NSC with an amendment to the Law on the National Security Council:

- The extended executive and supervisory powers of the Secretary General of the NSC. In particular, the provision empowering him to follow up, on behalf of the President and the Prime Minister, the implementation of any recommendation made by the NSC has been abrogated.

- Unlimited access of the NSC to any civilian agency has also been abrogated.

- The post of Secretary General will no longer be reserved exclusively for a military person. The frequency of the NSC meetings has been modified, so that it will meet every two months instead of once a month.

- The transparency of defense expenditures will be enhanced. The Court of Auditors will now be authorized to audit accounts and transactions of all types of organisations including state properties owned by the armed forces. The audit of the Court is still subject to the restrictions under Article 160 of the Constitution under which the confidentiality of national defense is established. ${ }^{66}$

The 2003 Regular Report, on the other hand, states that "the Armed Forces continue to enjoy a substantial degree of autonomy in preparing and establishing the defense budget and in public procurement in the defense-related area." ${ }^{, 67}$ The report gives utmost importance to "the alignment of civilian control of the military with practice in the EU member states, the withdrawal of military representation from civilian bodies and full control of the Parliament on the defense budget."68

\section{The Future Prospects for More Democratic Control}

As seen from the preceding analysis, the conditions that surround Turkey's EU candidacy have certainly contributed to a change in the weltanschauung of 
the Turkish military, since it is one of the key elements of the long-term guarantee of keeping the military in their barracks. ${ }^{69}$ Turkey's EU candidacy and the subsequent emphasis on increasing democracy will most probably continue to impact the military and put more pressure on them to become more transparent and accountable to the public. In this sense, we can argue that the EU candidacy has enhanced the prospects for increased democratic civil-military relations in the future.

On the other hand, Turkey's EU candidacy and its determination to fulfill the political criteria to become a full member constitute an important challenge to the military's traditional role as guardian of the Republic. Although the Turkish military is aware that staging a classical coup d'état has become quite difficult due to domestic and international pressures, it still considers itself the guardian of Kemalist principles and values, and thus insists on retaining a certain degree of autonomy over its own affairs. The military's adoption of a more subtle approach to achieve its political objectives is evident in the postmodern coup of February 28,1997 . Faced with the threat of reactionary Islam, it did not stage a coup as in the past, but instead exerted quite sophisticated political pressure and took measures via the NSC to deal with the perceived Islamic threat.

Although the military seems to be willing to limit its own power in some areas and allow a degree of civilian control, as seen in the example of the reform packages that amended the 1982 Constitution, there are certain spheres that the military seems to consider vitally important for national interests. On these matters, at least for the foreseeable future, they will probably not change their stance. One such issue is accountability of the chief of the general staff to the prime minister. Despite pressure from the EU, the military insists that this arrangement is a necessity that stems from the historical and strategic conditions unique to Turkey.

It is also important to note that without sufficient knowledge of the quality, nature, and functioning of democracy in Turkey, it is not possible to predict the degree of democratic control over the military in the near future. Civilmilitary relations in Turkey are determined, to a great extent, by the role played by the civilians. The military has intervened mostly because of the weaknesses of the Turkish political system and poor political leadership. This argument is also voiced by one of the senior generals, who stated:

None of us are willing to take control of this country or to become involved in politics. But while some bodies within the Turkish government are in a continuing state of ignorance and negligence, we have no other option... This should not be seen as the Turkish military becoming overly involved in Turkish politics or pressuring politicians. Everybody should understand the Turkish military's sensitivity on 
Turkey's interests both at home and abroad. Of course, we respect the Constitution and the laws by which we receive our responsibility and power. We are always ready to cooperate with governments that are working sincerely. But there are vital issues for us on which we can not make any concession. ${ }^{70}$

As discussed by Cottey, Edmunds, and Forster, civilian politicians in some CEEC countries have sometimes attempted to draw the military into politics in order to gain the perceived advantage of being supported by or associated with the armed forces. ${ }^{71}$ The same situation holds true in the Turkish case. For instance, during the "indirect intervention" of 1997, one can observe that the center-left parties (which also claimed to be representing the secular segments of the society) were trying to persuade the military to take measures against the rise of the reactionary activities of Islamists. In the absence of responsible civilian elites and political parties, the military, ironically, remains and will continue to remain the most credible institution, in the eyes of the Turkish people, to save democracy when it falls under attack. Therefore, in Turkey the more imminent threats of political Islam and Kurdish separatism take precedence over the democratic control of the Turkish military.

\section{Conclusion}

In conclusion, one can argue that EU candidacy has contributed to democratization of civil-military relations in Turkey. However, there are certain limits to its impact, and this will probably remain the case $\mathrm{n}$ the foreseeable future. Although the Turkish military will probably not attempt a direct coup d'état or show tendencies toward praetorianism-behaviors which are labeled first generation problems by Cottey, Edmunds, and Forster-the armed forces are not ready to become a postmodern military yet, and the second generation problems of democratic consolidation, effectiveness, and efficiency will continue to persist in the near future. Only with the perceived disappearance of separatist tendencies, a decreasing intensity of political Islam, and more civilian empowerment and responsibility can the prospects for more democratic control over the military, and therefore a more consolidated democracy, be realized in Turkey.

\section{Notes}

1. Christopher Dandeker, "New Times for the Military: Some Sociological Remarks on the Changing Role and Structure of the Armed Forces of the Advanced Societies," in The Sociology of the Military, ed. Giuseppe Caforio (Cheltenham, Northampton: An Elgar Reference Collection, 1998): 575. 
2. Charles C. Moskos, John Allen Williams, and David R. Segal, The Postmodern Military. Armed Forces After the Cold War (Oxford: Oxford University Press, 2000).

3. M. Kaldor and R. Luckham, "New Types of Conflict." Paper presented at the Centre for Defense and Security Management workshop on security structures and democratic governance, University of Witwaterstrand, September 18-20, 2000.

4. S. Sarkesian, J.A. Williams, and F.B. Bryant, Soldiers, Society and National Security (Boulder, CO: Lynne Rienner Publishers, 1995), 140.

5. Andrew Cottey, Timothy Edmunds, and Anthony Forster, "The Second Generation Problematic: Rethinking Democracy and Civil-Military Relations," Armed Forces \& Society 29, 1 (Fall 2002): 36 .

6. Andrew Cottey and Timothy Edmunds, "Democratizing Civil-Military Relations in Central and Eastern Europe: The Transnational Dimension," Internet Resource Centre (March 2000). Available online at http://www.bristol.ac.uk/Depts/GRC/CMR/TCMR\%20Papers/TCMR\%202.1.htm

7. Ümit Cizre, "Problems of Democratic Governance of Civil-Military Relations in Turkey and the European Union Enlargement Zone," European Journal of Political Research 43, 1 (January 2004): 109.

8. M. A. Birand, Shirts of Steel. An Anatomy of the Turkish Armed Forces (London: I. B. Tauris and Co. Ltd, 1991).

9. Aylin Güney, "Challenges to the Role of the Turkish Military in the Light of the Post-Cold War Developments," in Political Armies, ed. Kees Koonings and Dirk Kruijt (London: Zed Publishers, 2002).

10. Ümit Cizre-Sakallığlu, "The Anatomy of the Turkish Military's Autonomy,” Comparative Politics 29, 4 (January 1997): 151-165.

11. Metin Heper and Aylin Güney, "The Military and Democracy in the Third Turkish Republic,” Armed Forces \& Society 22, 4 (Summer 1996): 637.

12. Robin Luckham, in his article "A Comparative Typology of Civil-Military Relations," has referred to the Turkish case as a "covert guardianship." Here we borrow his definition of covert guardianship as well to denote the basic characteristic of the traditional guardianship role of the Turkish military. He states that in this model "more indirect still, the military may act in such a way as to support over the long run a political order that it considers capable of following the national interest and providing it with adequate support in the pursuit of national security. The military may submerge itself politically for a considerable time and yet retain the capacity for direct political action when so required." The article has been reproduced in The Sociology of the Military, ed. Giuseppe Caforio (Cheltenham, Northampton: An Elgar Reference Collection, 1998), 480.

13. George Harris, "The Role of the Military in Turkey in the 1980s: Guardians or DecisionMakers?" in State, Democracy and the Military: Turkey in the 1980s, ed. Metin Heper and Ahmet Evin (Berlin: Walter de Gruyter, 1988), 177-200.

14. Kees Koonings and Dirk Kruijt, "Military Politics and the Mission of Nation Building." Paper presented at the International Conference on Political Armies sponsored by Utrecht University, Utrecht, the Netherlands, April 13-14, 2000).

15. Aylin Güney, "Challenges to the Role of the Turkish Military," 162. 
16. Ümit Cizre, "Politics and Military in Turkey into the 21st Century," EUI Working Papers RSC No. 2000/24, Mediterranean Programme Series (European University Institute, 2000), 4.

17. Gerassimos Karabelios, "The Evolution of Civil-Military Relations in Post-War Turkey, 198095," Middle Eastern Studies 35, 4 (October 1999): 151.

18. Nilüfer Narlı, “Civil-Military Relations in Turkey,” Turkish Studies 1, 1 (Spring 2000): 119.

19. Birand, Shirts of Steel, 59.

20. Metin Heper and Aylin Güney, "The Military and Consolidation of Democracy: The Recent Turkish Experience," Armed Forces \& Society 26, 4 (Summer 2000): 636.

21. S. Ergin, "Gölcük Gecesi [The Night of Gölcük, 2 Interviews with the Retired Commander of Navy Salim Dervişoğlu]," Hürriyet, November 2, 1999.

22. Birand, Shirts of Steel, 75.

23. H. Özdemir, Silahlı Kuvvetler Sivil Otorite İlişkisinin Yeniden Düzenlenmesi [The reorganization of the relations between the armed forces and the civilian authority] (Türkiye Sosyal Ekonomik Siyasal Araştırmalar Vakfı, 1991).

24. Ş. İba, Ordu Devlet Siyaset (İstanbul: Çiviyazıları, 1998).

25. Ibid., 200.

26. Ahmet Evin, "Demilitarization and Civilianization of the Regime," in Politics in the Third Turkish Republic, ed. Metin Heper and Ahmet Evin (Boulder, CO: Westview Press, 1994), 23-40.

27. Gerassimos Karabelios, "A Brief Overview of the Evolution of Civil-Military Relations in Albania, Greece and Turkey During the Post-World War II Period," Journal of Political and Military Sociology 31, 1 (Summer 2003): 64.

28. Ahmet Evin, "Demilitarization and Civilianization of the Regime," in Politics in the Third Turkish Republic (see note 26), 33-34.

29. The military officials also stated that in the Constitution, they are held accountable to the Council of Ministers and the prime minister is the head of the Council. Therefore, there is not an undemocratic practice as it has been claimed. Radikal, January 11, 2004.

30. Ş. İba, Milli Güvenlik Devleti: Dünyada ve Türkiye’de Belgeleriyle Milli Güvenlik İdeolojisi ve Kurumlaşma (İstanbul: Çiviyazıları, 1998).

31. Metin Heper and Aylin Güney, "The Military and the Consolidation of Democracy," 635-657.

32. "Parti Kapatmaya Götüren Sözler" [The Words that Lead to Party Closure], Milliyet (İstanbul daily), January 17, 2000.

33. European Court of Human Rights (Third Section), "Case of Refah Partisi [Welfare Party] and Others v. Turkey," (Strasbourg, July 31, 2001).

34. “Parti Kapatmaya Götüren Sözler,” Milliyet, January 17, 1998.

35. "Refah'1 Yakan 7'li" [The Group of Seven that Failed the Welfare Party], Hürriyet (İstanbul daily), January 17, 1998.

36. Ibid. 
37. “Parti Kapatmaya Götüren Sözler,” Milliyet, January 17, 1998.

38. Ibid.

39. “Tarikat Saltanatı” [Reign of the Religious Orders], Hürriyet, January 12, 1997.

40. Later on, in a January 2001 television program, a former military commander (Erol Özkasnak) labeled this intervention as a "post-modern coup."

41. The WSG was established to monitor reactionary activities and plan necessary measures. Among other things, the WSG was to find out which groups might support the military and which groups would support the militant Islamists if an Islamic uprising did take place. The military had decided that if such an uprising took place, it would act unilaterally, under the provisions of Act 35 of the 1961 Internal Service Act of the Turkish Armed Forces. That act stipulated that "the Armed Forces are responsible for looking after and safeguarding ... the Turkish Republic and the characteristics of which are delineated in the Constitution."

42. Ergin, Sedat, "Evet Sivillerden Şikayetçiyiz" [Yes, we complain about the Civilians], Hürriyet, November 4, 1999

43. Ibid.

44. “AB Türkiye'nin Yararına [The European Union Membership is Useful for the Interests of Turkey], Milliyet (Istanbul daily), December 18, 1999.

45. Milliyet, April 6, 2000.

46. “MGK Snag in Copenhagen Criteria,” Turkish Daily News, June 24, 2000.

47. Ergin, Sedat, "Evet Sivillerden Şikayetçiyiz" [Yes, we complain about the Civilians], Hürriyet, November 4, 1999.

48. Demir, Metehan, "Military Warns Europe that Excluding Turkey from Europe will cost too much," Turkish Daily News, November 13, 1997.

49. Ibid.

50. Ibid.

51. Ibid.

52. Presidency Conclusions, December 10-11, 1999, Helsinki European Council, available online at http://europa.eu.int/council/off/conclu/dec99/dec99_en.htm

53. "İsveçli Bakan: AB İçin 2004 İyimser Bir Hedef" [Swedish Minister: 2004 is a Optimistic Target for the EU], Hürriyet, February 19, 2000.

54. Çevikcan, Serpil, "MGK Genişleyebilir,” Milliyet, July 25, 2000.

55. Çakırözer, Utku, “Ordu-Basın Beyin Fırtınası," [Military-Media Brainstorming] Milliyet, September 23, 2000.

56. Evren, Değer, "Genelkurmay AB için Çalışma Grubu Kurdu,” Radikal, January 11, 2000.

57. European Commission, Regular Report on Turkey's Progress towards Accession, November $8,2000$.

58. Saribrahimoğlu, Lale, "Turkey and EU Fail to Bridge Gap on ESDP," Turkish Daily News, November 13, 2001. 
59. “Armed Forces on the Offensive,” Turkish Daily News, January 12, 2001.

60. Ibid.

61. Demir, Metehan, "Kıvrıkoğlu IMF Bizi Zor Durumda Bırakır,” Hürriyet, July 8, 2001.

62. “Türkiye İmajını Yenilemeli” [Turkey has to Renew its Image], Hürriyet, July 4, 2001.

63. “General Kıvrıkoğlu Blasts Erdoğan,” Turkish Daily News, April 25, 2002.

64. “Controversy at MGK Expected Today,” Turkish Daily News, August 20, 2002.

65. Ibid.

66. European Commission, 2003 Regular Report on Turkey's Progress towards Accession, available online at http://europa/eu/int/comm/enlargement/report_2003/pdf/rr_tk_final.pdf

67. Ibid.

68. Ibid.

69. Tanel Demirel, “The Turkish Military's Decision to Intervene: 12 September 1980," Armed Forces \& Society 29, 2 (Winter 2003): 275.

70. Demir, Metehan, "Military Bridges Foreign Policy Gaps,” Turkish Daily News, May 11, 1998.

71. Cottey, Edmunds, and Forster, "The Second Generation Problematic," 49. 